\title{
EFFECT OF HYPOXIA ON THE EXPRESSION OF CCN2, PLAU, PLAUR, SLURP1, PLAT AND ITGB1 GENES IN ERN1 KNOCKDOWN U87 GLIOMA CELLS
}

\author{
O. H. MINCHENKO', A. P. KHARKOVA', K. I. KUBAICHUK', \\ D. O. MINCHENKO ${ }^{1,2}$, N. A. HLUSHCHAK ${ }^{1}$, O. V. KOVALEVSKA ${ }^{1}$ \\ ${ }^{1}$ Palladin Institute of Biochemistry, National Academy of Sciences of Ukraine, Kyiv; \\ e-mail: ominchenko@yahoo.com; \\ ${ }^{2}$ Bogomolets National Medical University, Kyiv, Ukraine;
}

The endoplasmic reticulum stress is an important factor of tumor growth and is induced in cancer cells. We have studied the effect of ERN1 knockdown as well as hypoxia on the expression of genes encoding factors, which control cell proliferation, in U87 glioma cells. It was shown that the complete blockade of ERN1 enzyme function leads to an increase of the PLAT (tissue plasminogen activator), CCN2 (CCN family member 2), and ITGBI (integrin $\beta$-1) as well as to a decrease of PLAU (plasminogen activator, urokinase), PLAUR (plasminogen activator, urokinase receptor), and SLURP1 (secreted LY6/PLAUR domain containing 1) mRNA expressions. Moreover, we have shown that hypoxia does not affect the expression level of ITGB1 mRNA, but increases that of CCN2, PLAUR, SLURP1, and PLAT mRNA and decreases the expression level of only PLAU mRNA in control glioma cells. At the same time, in ERN1 knockdown glioma cells the expression level of PLAU, PLAUR, and SLURP1 mRNA is decreased under hypoxia, but PLAT and ITGB1 mRNA expression levels are increased under these experimental conditions. Thus, results of this study have shown that the expression level of all studied genes is affected by ERN1 knockdown as well as by hypoxia and that the effect of hypoxia mostly depends on ERN1 signaling enzyme function.

K ey word s: mRNA expression, PLAU, PLAUR, SLURP1, PLAT, CCN2, ITGB1, ERN1 knockdown, glioma cells, hypoxia.

$\mathrm{T}$ he endoplasmic reticulum stress is associated with accumulation of unfolded proteins in the endoplasmic reticulum and is an important factor of malignant tumor growth [1, 2]. It controls the neovascularization and proliferation processes $[3,4]$. This adaptive unfolded protein response is activated upon the accumulation of misfolded proteins in the endoplasmic reticulum and is mediated by several endoplasmic reticulum-resident sensors named ERN1 (from endoplasmic reticulum to nuclei-1), PERK (PRK-like ER kinase), and ATF6 (activating transcription factor 6); however, bifunctional enzyme ERN1 is the dominant sensor and signaling system $[2,4,5]$. The endoplasmic reticulum stress participates in the early cellular response to the accumulation of misfolded proteins in the lumen of the endoplasmic reticulum [1, 2]. Activation of the unfolded protein response tends to adapt cells for survival or, alternatively, to enter cell death programs $[2,6]$. Hypoxia is associated with glioma development and locally induces an adaptive response which imparts to tumor cells an enhanced survival and a more agressive behaviour $[3,7,8]$.

The signaling enzyme ERN1 has endoribonuclease activity which is responsible for degradation of a specific subset of mRNA and initiation of the alternative splicing of pre-XBP1 (X-box binding protein 1) mRNA $[6,9,10]$. Mature XBP1 mRNA splice variant encodes a transcription factor that stimulates the expression of more than six hundred unfolded protein response-specific genes $[10,11]$. Moreover, the spliced form of XBP1 nuclear translocation is enhanced through phosphorylation by different protein kinases $[12,13]$. It was also shown that the alternative splice-variant of XBP1 interacts with the FOXO1 (forkhead box O1) transcription factor and directs it toward proteasome-mediated degradation [14].

Malignant gliomas are highly aggressive tumors and are characterized by marked angiogenesis and extensive tumor cell invasion into the normal brain parenchyma [2]. Hypoxia as well as endoplas- 
mic reticulum stress is associated with glioma development and locally induces an adaptive response which imparts to tumor cells an enhanced survival and a more agressive behaviour [2]. It was shown that the complete blockade of ERN1 signal transduction pathway has anti-tumor effects in lung cancer and glioma cells $[6,15,16]$. A better knowledge of tumor responses to hypoxia and endoplasmic reticulum stress is required to elaborate therapeutical strategies of cell sensibilization and angiogenesis inhibition, based on the blockade of survival mechanisms.

Cell proliferation regulatory proteins such as PLAU, PLAUR, SLURP1, CCN2, PLAT, and ITGB1 play an important role in malignant tumor growth. Thus, it was recently shown that PLAU (plasminogen activator, urokinase) and its receptor PLAUR are responsible for both tumor cell migration and proliferation $[17,18]$. Moreover, PLAUR mediates the proteolysis-independent signal transduction activation effects of PLAU and regulates single-chain PLAUmediated angiogenesis through ITGB1 ( $\beta 1$-integrin) and VEGFR2 (vascular endothelial growth factor receptor 2) [19]. It is important to note that microRNA 137 can induce G1 cell cycle arrest in lung cancer cells as well as promotes transendothelial migration of cancer cells through beta1 integrin [20]. It was also shown that activation of $\alpha(7)$-nAChR $(\alpha(7)-n-$ acetyl choline receptor) by SLURP1 (secreted LY6/ PLAUR domain containing 1) leads to up-regulation of NF-kB (nuclear factor kappaB) expression due to activation of the RAF1/MEK1/ERK1/2 cascade that proceeds via two complementary signaling pathways [21].

Recently it was shown that CCN2 (CCN family member 2) protein also known as IGFBP8 (insulinlike growth factor binding protein 8) plays a role in cell proliferation, differentiation, angiogenesis, as well as cell adhesion in many cell types, and is related to platelet-derived growth factor [22]. Furthermore, loss of connective tissue growth factor activates miR-18b and promotes cell growth in nasopharyngeal carcinoma. It was also shown that integrin beta1 is involved in a variety of processes including cell proliferation, migration and invasion $[19,20,23]$.

The main goal of this study was to investigate the role of the expression of genes related to the control of cell proliferation (CCN2, PLAU, PLAUR, SLURP1, PLAT, and ITGB1) in glioma U87 cells with ERN1 knockdown and its regulation upon hypoxia.

\section{Materials and Methods}

Cell Lines and Culture Conditions. The glioma cell line U87 was obtained from ATCC (USA) and grown in high glucose (4.5 g/l) Dulbecco's modified Eagle's minimum essential medium (DMEM; Gibco, Invitrogen, USA) supplemented with glutamine (2 mM), 10\% fetal bovine serum (Equitech-Bio, Inc., USA), penicillin (100 units/ml; Gibco) and streptomycin $\left(0.1 \mathrm{mg} / \mathrm{ml}\right.$; Gibco) at $37^{\circ} \mathrm{C}$ in a $5 \% \mathrm{CO}_{2}$ incubator. In this work we used two sublines of this glioma cell line. One subline was obtained by selection of stable transfected clones with overexpression of vector (pcDNA3.1), which was used for creation of dominant-negative constructs (dnERN1). This untreated subline of glioma cells (control glioma cells) was used as control 1 in the study of hypoxic effects on the expression level of CCN2, PLAU, PLAUR, SLURP1, PLAT and ITGB1 genes. The other subline was obtained by selection of stable transfected clones with overexpression of dnERN1 and has suppressed both protein kinase and endoribonuclease activities of ERN1 signaling enzyme. These cells were obtained from prof. M. Moenner (France) [2, 15]. The expression level of PLAU, PLAUR, SLURP1, PLAT, CCN2 and ITGB1 genes in these cells was compared with that in the cells, transfected by vector (control 1), but this untreated subline was also used as control 2 for investigation the effect of hypoxia on the expression level of these genes under blockade ERN1 function. Hypoxic condition was created in special incubator with 3\% oxygen and 5\% carbon dioxide levels; culture plates with complete DMEM were exposed to these conditions for $16 \mathrm{hrs}$.

The suppression level of ERN1 enzymatic activity in glioma cells that overexpress a dominantnegative construct of endoplasmic reticulum-nuclei-1 (dnERN1) was previously shown by analysis of the expression of XBP1 alternative splice variant (XBP1s), a key transcription factor in ERN1 signaling, and phosphorylated isoform ERN1 using cells treated by tunicamycin $(0.01 \mathrm{mg} / \mathrm{ml}$ during 2 hours) [24].

RNA isolation. Total RNA was extracted from glioma cells using Trisol reagent (Invitrogen) as described [24]. RNA pellets were washed with $75 \%$ ethanol and dissolved in nuclease-free water. For additional purification RNA samples were precipitated with 95\% ethanol and re-dissolved again in nucleasefree water.

Reverse transcription and quantitative PCR analysis. QuaniTect Reverse Transcription Kit (QIA- 
GEN, Germany) was used for cDNA synthesis as described previously [25].

The expression levels of PLAU, PLAUR, SLURP1, PLAT, CCN2, and ITGB1 mRNA were measured in glioma cell line U87 and its sublines (clone 1C5) by real-time quantitative polymerase chain reaction of cDNA using "Mx 3000P QPCR" (Stratagene, USA) and Absolute qPCR SYBRGreen Mix (Thermo Fisher Scientific, ABgene House, UK). Polymerase chain reaction was performed in triplicate. For amplification of PLAU (urokinase plasminogen activator) cDNA we used next forward and reverse primers: $5^{\prime}$-TCACCACCAAAATGCTGTGT-3' and (5'-AGGCCATTCTCTTCCTTGGT-3', correspondingly. The nucleotide sequences of these primers correspond to sequences 1210-1229 and 1432-1413 of human PLAU cDNA (GenBank accession number NM_002658). The size of amplified fragment is $223 \mathrm{bp}$. The amplification of PLAUR (plasminogen activator, urokinase receptor) cDNA was performed using forward primer (5'-GCCTTACCGAGGTTGTGTGT-3') and reverse primer (5'-TGTTGCAGCATTTCAGGAAG-3'). These oligonucleotides correspond to sequences 486-505 and 809-790 of human PLAUR cDNA (GenBank accession number NM_002659). The size of amplified fragment is $324 \mathrm{bp}$. The amplification of SLURP1 (secreted LY6/PLAUR domain containing 1) cDNA for real time RCR analysis was performed using two oligonucleotides primers: forward -5 '-CCTGATCTTCTGCTGCTTCC-3' and reverse $-5^{\prime}$-CCTGATCTTCTGCTGCTTCC-3'. The nucleotide sequences of these primers correspond to sequences 293-312 and 476-457 of human SLURP1 cDNA (GenBank accession number NM_020427). The size of amplified fragment is $184 \mathrm{bp}$. For amplification of CCN2 (CCN family member 2) cDNA we used next forward and reverse primers: 5'-ACTGTCCCGGAGACAATGAC-3' and 5'-TGCTCCTAAAGCCACACCTT-3', correspondingly. The nucleotide sequences of these primers correspond to sequences 1189-1208 and 1527-1508 of human CCN2 cDNA (GenBank accession number NM_001901). The size of amplified fragment is $339 \mathrm{bp}$. The amplification of PLAT (tissue plasminogen activator) cDNA for real time RCR analysis was performed using two oligonucleotides primers: forward - 5'-CAGCAGGCCCTGTACTTCTC-3' and reverse - 5'-GGCTTTGAGTCTCGATCTGG-3'. The nucleotide sequences of these primers correspond to sequences 501-520 and 772-753 of human PLAT cDNA (GenBank ac- cession number NM_000930). The size of amplified fragment is $272 \mathrm{bp}$. For amplification of ITGB1 (integrin $\beta-1$ ) cDNA we used forward (5'-CGAGGTCATGGTTCATGTTG- ${ }^{\prime}$ and reverse (5'-CAGTGTTGTGGGATTTGCAC-3') primers. The nucleotide sequences of these primers correspond to sequences 2354-2373 and 2647-2628 of human ITGB1 cDNA (GenBank accession number NM_002211). The size of amplified fragment is $294 \mathrm{bp}$. The amplification of beta-actin (ACTB) cDNA was performed using forward - 5'-GGACTTCGAGCAAGAGATGG-3' and reverse - 5'-AGCACTGTGTTGGCGTACAG-3' primers. These primer nucleotide sequences correspond to 747-766 and 980-961 of human ACTB cDNA (GenBank accession number NM_001101). The size of amplified fragment is $234 \mathrm{bp}$. The expression of $\beta$-actin mRNA was used as control of analyzed RNA quantity. The primers were received from Sigma-Aldrich (USA).

An analysis of quantitative PCR was performed using special computer program Differential expression calculator. Statistical analysis was performed according to Student's test using OriginPro 7.5 software. The values of PLAU, PLAUR, SLURP1, PLAT, CCN2, and ITGB1 mRNA expressions were normalized to the expression of $\beta$-actin mRNA and represented as percent of control (100\%). All values are expressed as mean \pm SEM from triplicate measurements performed in four independent experiments.

\section{Results and Discussion}

As shown in Fig. 1, the blockade of ERN1 enzyme, the major component of endoplasmic reticulum stress signaling, affects the expression level of CCN2, PLAU, PLAUR, SLURP1, PLAT, and ITGB1 mRNAs in U87 glioma cells, but in different ways. Thus, the expression level of CCN2, PLAT, and ITGB1 mRNAs is increased in glioma cells, being more significant for CCN2 and PLAT: more than 5 and 4 times, correspondingly. At the same time, the expression of three other genes (PLAU, PLAUR, and $S L U R P 1)$ is significantly decreased after blockade of ERN1 signaling enzyme function (Fig. 1). Thus, the expression levels of PLAU mRNA is decreased more than 3 times, but urokinase plasminogen activator receptor as well as SLURP1 mRNA expression level was more than twice less as compared to control glioma cells.

We have also studied the hypoxic regulation of these gene expressions. As shown in Fig. 2, the exposure of glioma cells under hypoxic condition 
leads to significant up-regulation of CCN2 mRNA expression level (+ 54\%) in control U87 glioma cells, but in ERN1 knockdown cells the effect of hypoxia had a reverse effect: CCN2 mRNA expression level is decreased (- 32\%) in these cells (Fig. 2). Another type of hypoxic regulation was shown for $P L A U$ gene. Thus, as shown in Fig. 3, an exposure of glioma cells under hypoxia leads to a 2-fold decrease of the expression level of PLAU mRNA in control U87 glioma cells; however, in ERN1 knockdown cells the effect of hypoxia was significantly less (- 27\%). At the same time, the expression of PLAUR mRNA in control U87 glioma cells is also increased (+ 21\%) like CCN2 mRNA and blockade of ERN1 signaling enzyme modifies the effect of hypoxia on this mRNA expression level (Fig. 4). Thus, in these glioma cells the expression level of PLAUR mRNA is decreased (- 31\%). Investigation of SLURP1 (secreted LY6/PLAUR domain containing 1) mRNA expression in U87 glioma cells has shown that the level of this mRNA expression is also affected by hypoxia in control as well as in ERN1 knockdown glioma cells like PLAUR mRNA (+ 23\% in control glioma cells and - 19\% in ERN1 knockdown cells (Fig. 5)).

We have also shown that hypoxia has significantly increased the expression level of PLAT
mRNA (+ 93\%) but did not affect the expression level of ITGB1 mRNA in control glioma cells (Fig. 6 and 7). At the same time, the blockade of ERN1 signaling enzyme leads to significant up- regulation of the expression of both PLAT and ITGB1 genes in U87 glioma cells: $+74 \%$ and $+22 \%$, correspondingly. Moreover, the knockdown of signaling enzyme ERN1 in U87 glioma cells leads to some morphological changes in these cells (Fig. 8) as well as to suppression of cell proliferation and growth of tumor originated from these cells $[15,16]$.

Results of this study clearly demonstrated that the expression levels of all tested genes (CCN2, PLAU, PLAUR, SLURP1, PLAT and ITGB1) encoding important regulatory factor, which control cell proliferation and participate in malignant tumor growth, is affected by ERN1 signaling enzyme knockdown. Moreover, the decrease of PLAU and PLAUR mRNA expression levels in glioma cells after blockade of ERN1 signaling enzyme function is argued with suppression of tumor growth from these cells $[15,16]$, because both PLAU and PLAUR are up-regulated in the tumors as well as are responsible for cell proliferation and migration [17, 18]. Furthermore, the decrease of SLURP1 mRNA expression in U87 glioma cells after ERN1 knockdown can also participate in the suppression of tumor growth be-

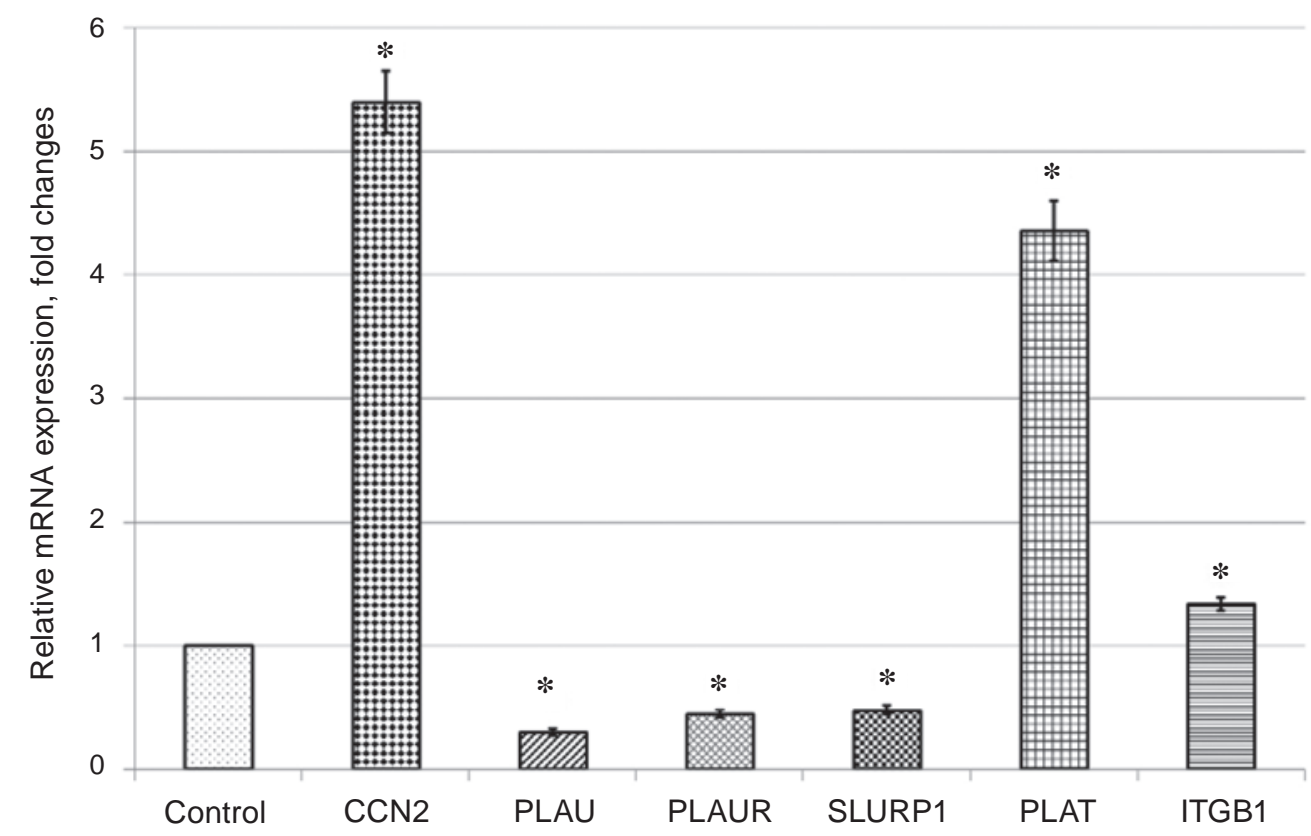

Fig. 1. The expression level of CCN2, PLAU, PLAUR, SLURP1, PLAT, and ITGB1 mRNAs in ERN1 knockdown U87 glioma cells (dnERN1). Control - cells, stable transfected by pcDNA3.1 (Vector). The level of these mRNA expressions was normalized to the $\beta$-actin and compared to the control (Vector, 100\%); $n=4 ; * P<0.05$ as compared to control 


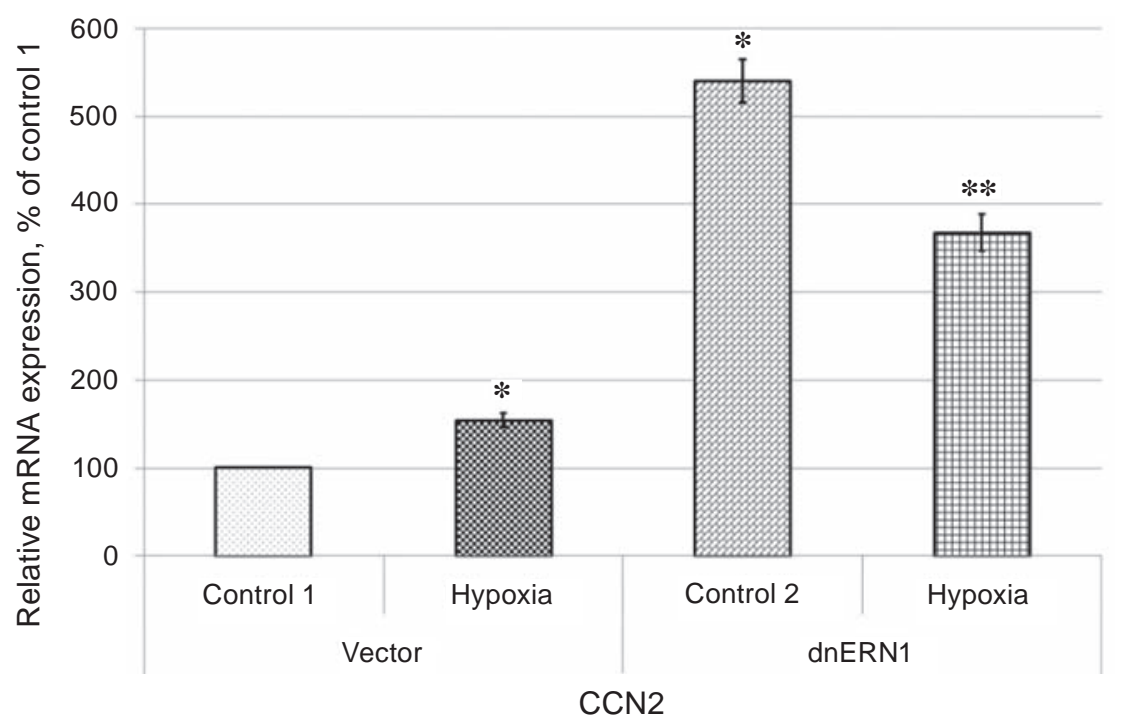

Fig. 2. Effect of hypoxia on the expression level of CCN2 (CCN family member 2) in U87 glioma cells, transfected with vector pcDNA3.1 (Vector) and ERN1 knockdown cells (dnERN1), measured by quantitative $P C R$. The level of CCN2 mRNA expression was normalized to the expression of $\beta$-actin. In Fig. 2-7 the changes in the expression of different mRNA in both types of glioma cells were compared to the control 1 (Vector, 100\%); $n=4 ; * P<0.05$ as compared to the control 1, ** $P<0.05$ as compared with the control 2 (dnERN1)

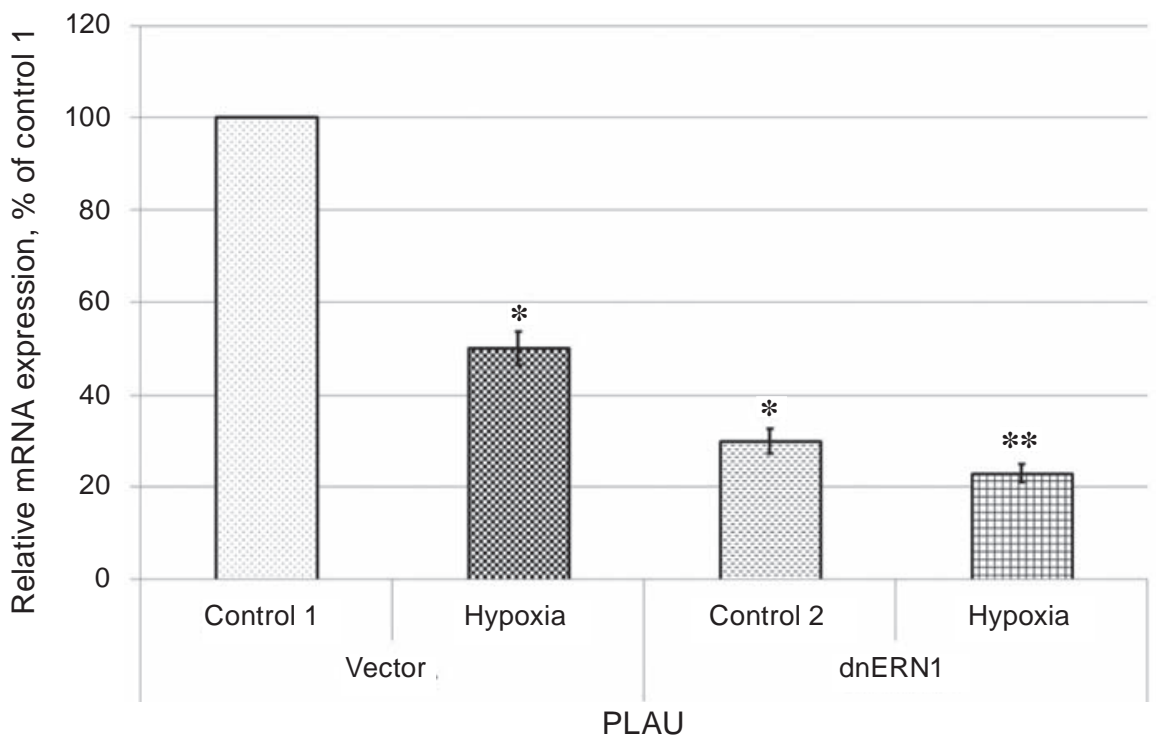

Fig. 3. Effect of hypoxia on the expression level of PLAU (urokinase plasminogen activator) mRNA in U87 glioma cells, stable transfected with vector pcDNA3.1 (Vector) and cells, stable transfected with dominant/ negative constructs of ERN1 signaling enzyme (dnERN1), measured by quantitative real-time PCR. The level of PLAU mRNA expression was normalized to the expression of $\beta$-actin

cause there is data that SLURP1 protein can activate protein kinases and up-regulate the NF-kB gene expression [21].

Protein CCN2 is a multifunctional protein and plays a role in cell proliferation, differentia- tion, and angiogenesis. At the same time, loss of CCN2 activates miR-18b and promotes cell growth in nasopharyngeal carcinoma [22]. Moreover, overexpression of MYC promoted vigorous tumor vascularization and growth without changes in VEGF 


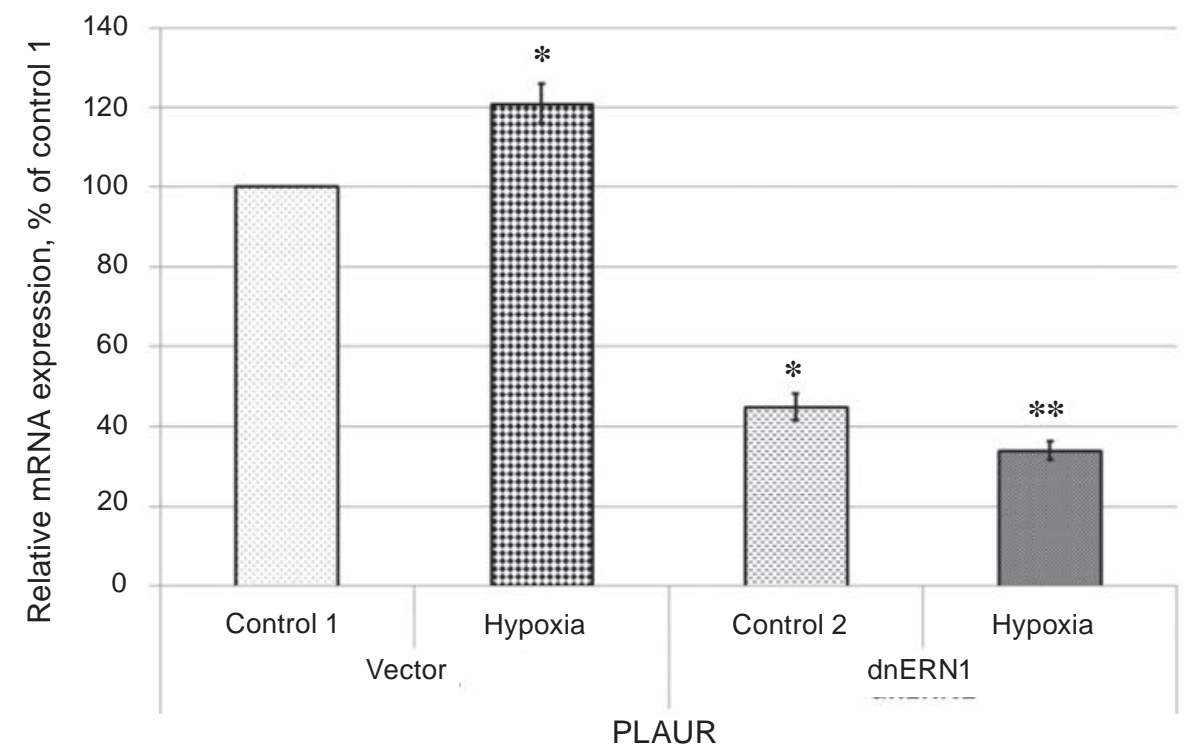

Fig. 4. Effect of hypoxia on the expression level of PLAUR (plasminogen activator, urokinase receptor) in U87 glioma cells, transfected with vector pcDNA3.1 (Vector) and ERN1 knockdown cells (dnERN1), measured by quantitative PCR. The level of PLAUR mRNA expression was normalized to the expression of $\beta$-actin

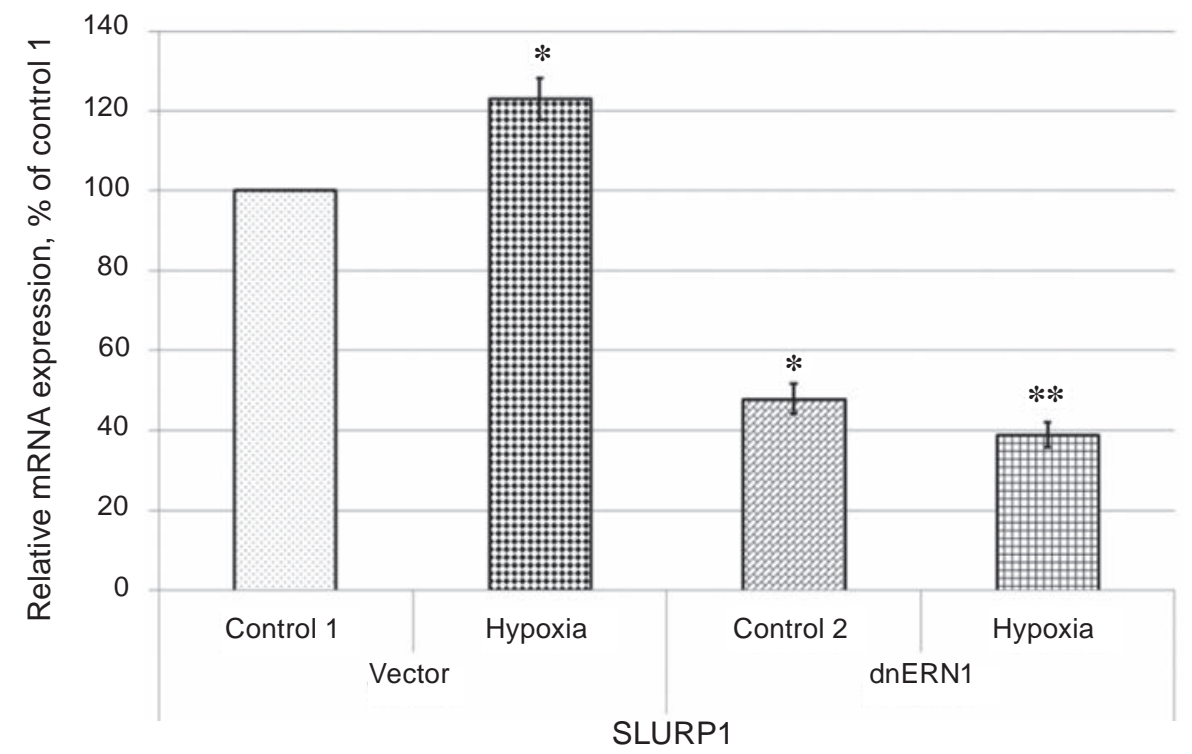

Fig. 5. Effect of hypoxia on the expression level of SLURP1 (secreted LY6/PLAUR domain containing 1) in U87 glioma cells, transfected with vector pcDNA3.1 (Vector) and ERN1 knockdown cells (dnERN1), measured by quantitative PCR. The level of SLURPI mRNA expression was normalized to the expression of $\beta$-actin

level, but enhanced neovascularization correlated with down-regulation of anti-angiogenic thrombospondin-1 and CCN2 which binds vascular endothelial growth factor and inhibits VEGF-induced angiogenesis [26, 27]. Thus, the increased level of CCN2 in our experiment with ERN1 knockdown glioma cells can also be responsible for the suppression of proliferation and growth of glioma, originated from these glioma cells.

We have also shown that PLAT mRNA expression was significantly up-regulated after the blockade of ERN1 signaling enzyme in glioma cells. These results are also agreed with data of Kenagy et al. [28] and Simard et al. [29]. Thus, Kenagy et 


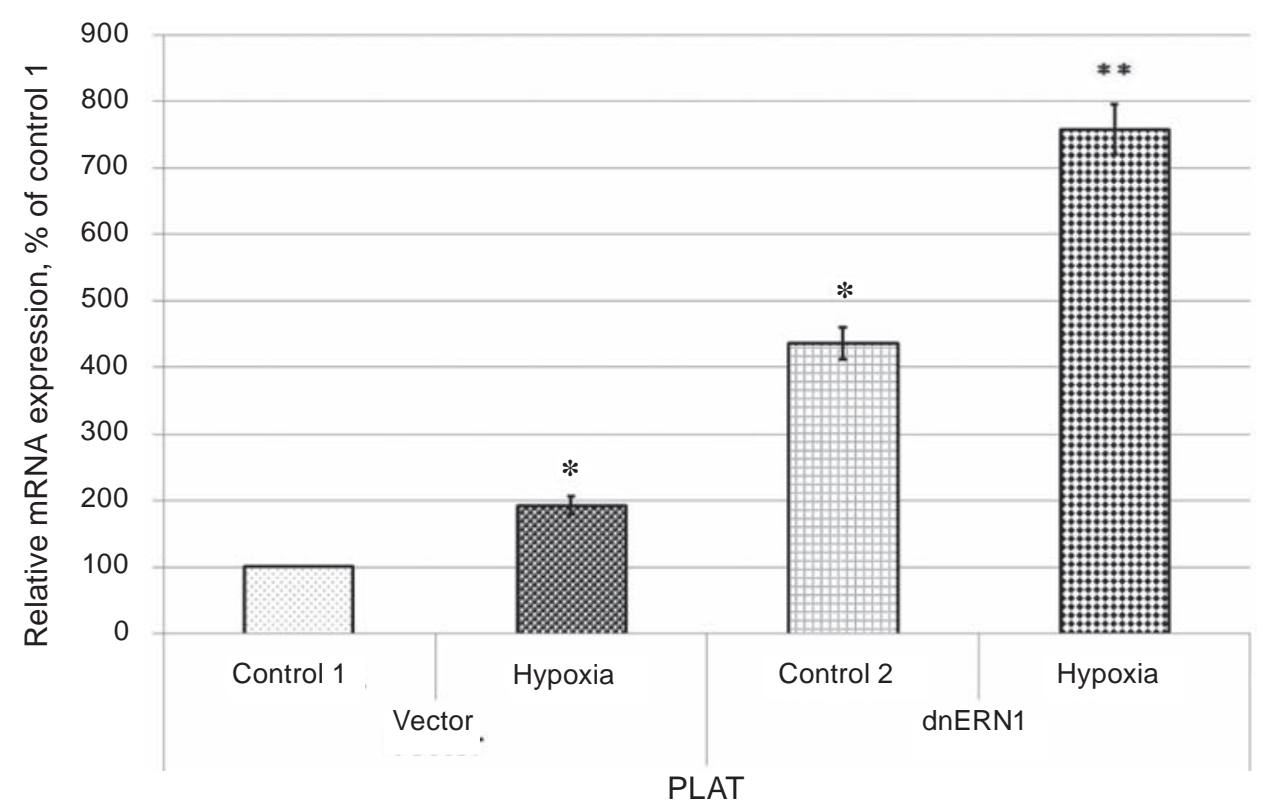

Fig. 6. Effect of hypoxia on the expression level of PLAT (tissue plasminogen activator) in U87 glioma cells, transfected with vector pcDNA3.1 (Vector) and ERN1 knockdown cells (dnERN1), measured by quantitative $P C R$. The level of PLAT mRNA expression was normalized to the expression of $\beta$-actin

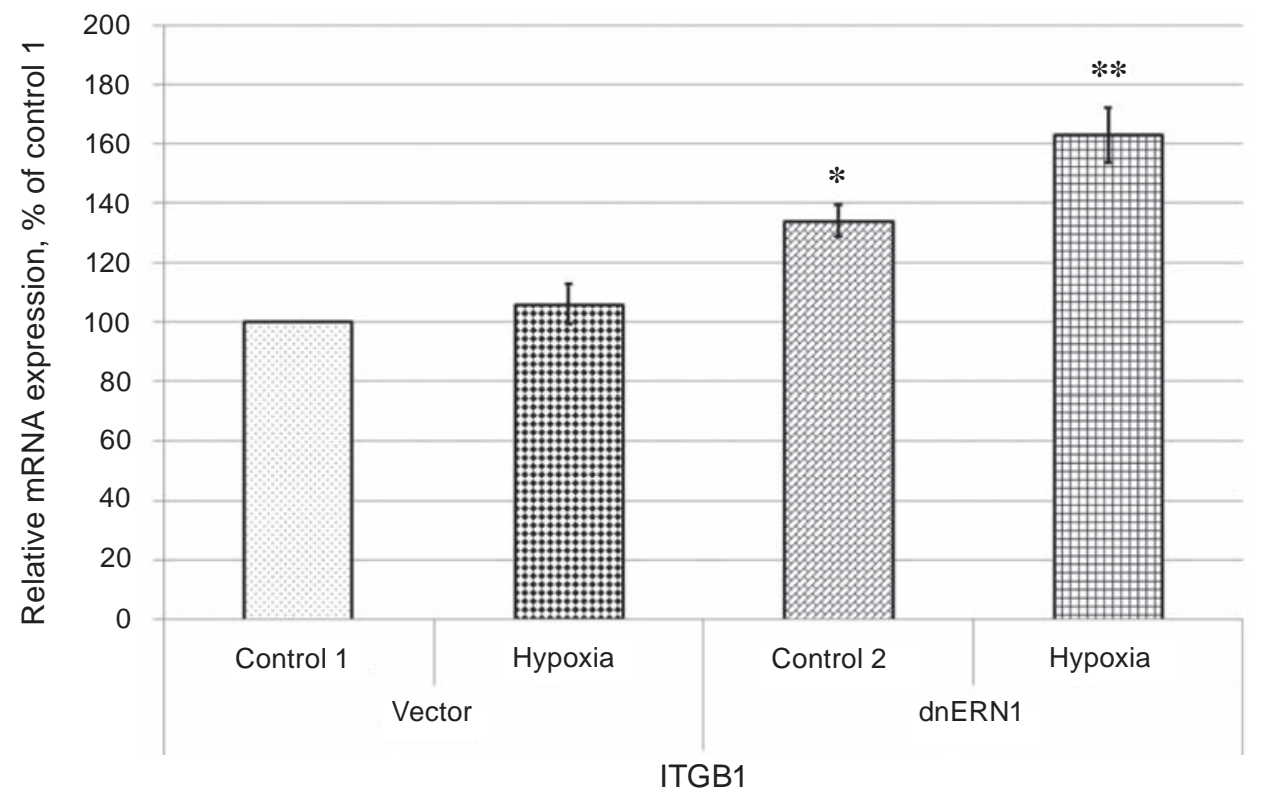

Fig. 7. Effect of hypoxia on the expression level of ITGB1 (integrin beta-1) in U87 glioma cells, transfected with vector pcDNA3.1 (Vector) and ERN1 knockdown cells (dnERN1), measured by quantitative PCR. The level of PLAUR mRNA expression was normalized to the expression of $\beta$-actin

al. [28] has shown that induction of cell death is associated with enhanced expression of several genes, including the PLAT, suggesting a mechanism by which the program of tissue atrophy coordinately removes extracellular matrix as cells die. It is possible, that overexpression of PLAT mRNA in ERN1 knockdown glioma cells is also in the suppression of these cells proliferation $[15,16]$ through induction of cell death. Moreover, induction of PLAT by shark cartilage extract plays an essential role in its antiangiogenic activity [30]. Integrin beta1 (ITGB1) is also involved in a variety of processes including cell 

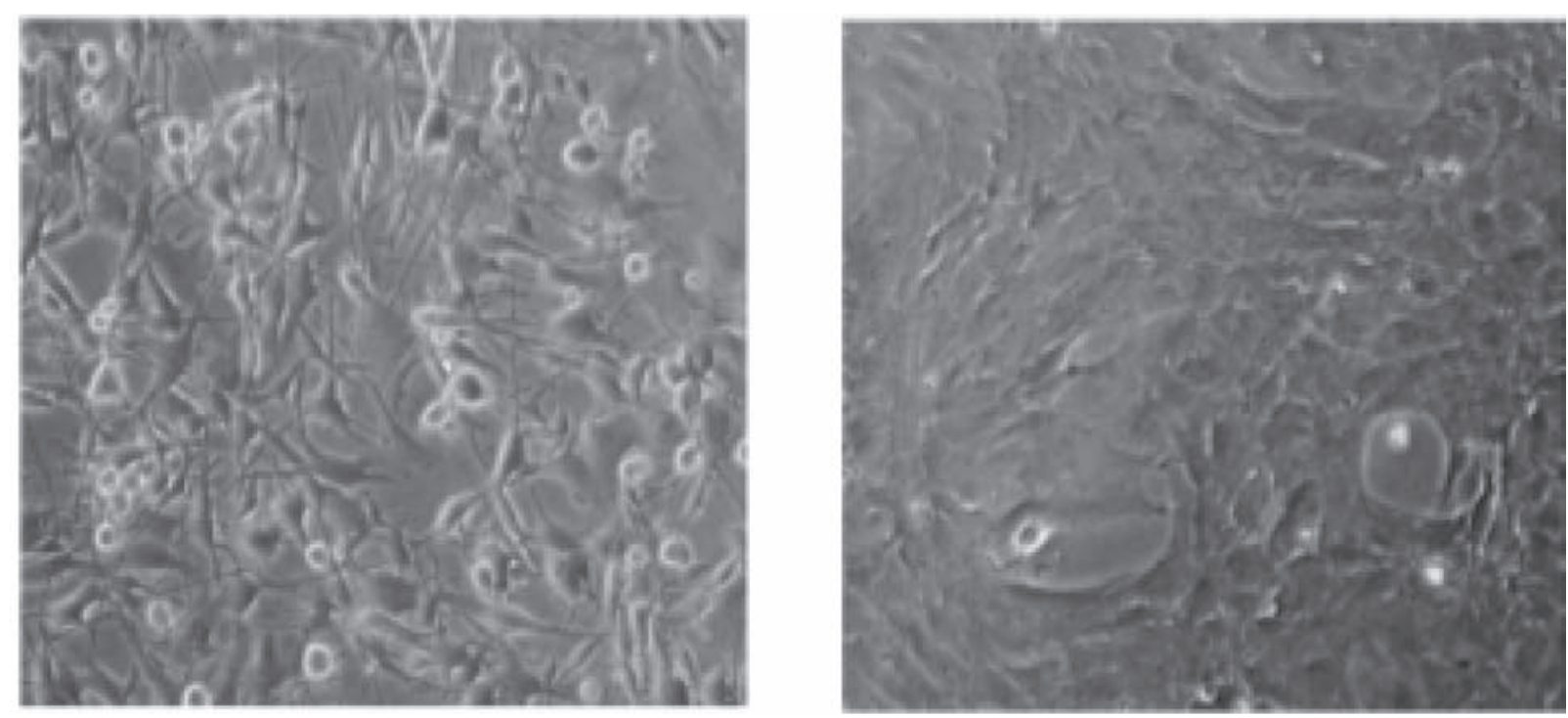

Fig. 8. Phase-contrast photomicrographs of control U87 glioma cells (left) and ERN1 knockdown U87 glioma cells (right) are shown after 3 days in culture

proliferation, migration and invasion as a component of receptors for collagen, fibronectin, laminin, and thrombospondin $[19,20,23]$. There is data that ITGB1 participates in PLAU-mediated angiogenesis through PLAUR [20]. It is possible that increase of ITGB1 expression in ERN1 knockdown glioma cells is connected with strong up-regulation of anti-angiogenic thrombospondin-1 and anti-proliferative effect of ERN1 blockade [30].

Moreover, we have shown that hypoxia affects the expression level of most studied genes and that
ERN1 knockdown modifies the effect of hypoxia on CCN2, PLAT, PLAU, PLAUR, and ITGB1 mRNA expressions. Moreover, these changes enhance the effect of ERN1 knockdown on PLAT, PLAU, PLAUR, SLURP1 and ITGB1 gene expressions. However, detailed molecular mechanisms of participation of these important growth regulatory factors in suppression of proliferation and growth of glioma from ERN1 knockdown glioma cells warrants further study. 


\section{ВПЛИВ ГІПОКСІЇ НА ЕКСПРЕСІЮ TEHIB CCN2, PLAU, PLAUR, SLURP1, PLAT ТА ITGB1 У КЛІТИНАХ ГЛІОМИ ЛІНІї U87 3 НОКДАУНОМ ГЕНА ERN1}

О. Г. Мінченко ${ }^{1}$, А. П. Харькова 1 , К. І. Кубайчук ${ }^{1}$ Д. О. Мінченко ${ }^{1,2}$, Н. А. Глушак 1 О. В. Ковалевська

${ }^{1}$ Інститут біохімії ім. О. В. Палладіна НАН України, Київ; e-mail: ominchenko@yahoo.com; ${ }^{2}$ Національний медичний університет ім. О. О. Богомольця, Київ, Україна

Стрес ендоплазматичного ретикулума $€$ посиленим у клітинах злоякісних пухлин. Він $\epsilon$ необхідним фактором росту пухлин. Вивчали експресію генів, що кодують важливі для проліферації клітин фактори, у клітинах гліоми лінії U87 з нокдауном гена ERN1 за умов гіпоксії. Встановлено, що нокдаун гена ERN1 призводить до збільшення рівня експресії мРНК PLAT (tissue plasminogen activator), CCN2 (CCN family member 2) та ITGB1 (integrin $\beta$-1), а також до зниження рівня експресії мРНК PLAU (urokinase plasminogen activator), PLAUR (plasminogen activator, urokinase receptor) та SLURP1 (secreted LY6/PLAUR domain containing 1). Було показано, що рівень експресії мРНК ITGB1 за умов гіпоксії істотно не змінюється в контрольних клітинах гліоми, але збільшується рівень експресії мРНК CCN2, PLAUR, SLURP1 та PLAT і знижується рівень експресії лише мРНК PLAU. У той же час у клітинах гліоми 3 нокдауном гена ERN1 рівень експресії мPHK PLAU, PLAUR та SLURP1 знижується за гіпоксії, але збільшується рівень експресії мРНК PLAT та ITGB1 за цих експериментальних умов. Таким чином, одержані нами дані свідчать про те, що рівень експресії всіх досліджених генів змінюється за блокади ERN1, а також за гіпоксії, і що ефект гіпоксії переважно залежить від функції сигнального ензиму ERN1.

Ключов і слова: експресія мРНК, PLAU, PLAUR, SLURP1, PLAT, CCN2, ITGB1, нокдаун гена ERN1, клітини гліоми, гіпоксія.

\section{ВЛИЯНИЕ ГИПОКСИИ НА ЭКСПРЕССИЮ ГЕНОВ CCN2, PLAU, PLAUR, SLURP1, PLAT И ITGB1 В КЛЕТКАХ ГЛИОМЫ ЛИНИИ U87 C НОКДАУНОМ ГЕНА ERN1}

\author{
А. Г. Минченко ${ }^{1}$, А. П. Харькова ${ }^{1}$, \\ К. И. Кубайчук ${ }^{1}$ Д. А. Минченко ${ }^{1,2}$, \\ Н. А. Глущак', О. В. Ковалевская ${ }^{1}$
}
${ }^{1}$ Институт биохимии им. А. В. Палладина НАН Украины, Киев; e-mail: ominchenko@yahoo.com;

${ }^{2}$ Национальный медицинский университет им. А. А. Богомольца, Киев, Украина

Стресс эндоплазматического ретикулума усиливается в клетках злокачественных опухолей. Он является необходимым фактором роста опухолей. Изучали экспрессию генов, кодирующих важные для пролиферации клеток факторы, в клетках глиомы линии U87 с нокдауном гена ERN1 при гипоксии. Установлено, что блокада ERN1 приводит к увеличению уровня экспрессии мРНК PLAT (tissue plasminogen activator), CCN2 (CCN family member 2) и ITGB1 (integrin $\beta-1)$, а также к снижению уровня экспрессии MPHK PLAU (urokinase plasminogen activator), PLAUR (plasminogen activator, urokinase receptor) и SLURP1 (secreted LY6/PLAUR domain containing 1). Было показано, что уровень экспрессии мРНК ITGB1 при гипоксии существенно не изменяется в контрольных клетках глиомы, но увеличивается уровень экспрессии мPHК CCN2, PLAUR, SLURP1 и PLAT и снижается уровень экспрессии только мРНК PLAU. В то же время, в клетках глиомы с нокдауном гена ERN1 уровень экспрессии мРНК PLAU, PLAUR и SLURP1 снижается при гипоксии, но увеличивается уровень экспрессии мРНК PLAT и ITGB1 при тех же экспериментальных условиях. Таким образом, полученные нами данные свидетельствуют о том, что уровень экспрессии всех исследованных генов изменяется при блокаде ERN1, а также при гипоксии, и что эффект гипоксии преимущественно зависит от функции сигнального энзима ERN1.

К л ю че вы е с ло в а: экспрессия мРНК, PLAU, PLAUR, SLURP1, PLAT, CCN2, ITGB1, нокдаун гена ERN1, клетки глиомы, гипоксия. 


\section{References}

1. Zhang K., Kaufman R. J. The unfolded protein response: a stress signaling pathway critical for health and disease // J. Biol. Chem. - 2004. 279, N 25. - P. 25935-25938.

2. Moenner M., Pluquet O., Bouchecareilh M., Chevet $E$. Integrated endoplasmic reticulum stress responses in cancer // Cancer Res. 2007. - 67, N 22. - P. 10631-10634.

3. Bi M., Naczki C., Koritzinsky M., Fels D., Blais J., Hu N., Harding H., Novoa I., Varia M., Raleigh J., Scheuner D., Kaufman R. J., Bell J., Ron D., Wouters B. G., Koumenis C. ER stressregulated translation increases tolerance to extreme hypoxia and promotes tumor growth // EMBO J. - 2005. - 24, N 19. - P. 3470 -34815.

4. Fels D. R., Koumenis C. The PERK/eIF2a/ATF4 module of the UPR in hypoxia resistance and tumor growth // Cancer Biol. Ther. - 2006. - 5, N 7. - P. 723-728.

5. Korennykh A. V., Egea P. F., Korostelev A. A., Finer-Moore J., Zhang C., Shokat K. M., Stroud R. M., Walter P. The unfolded protein response signals through high-order assembly of Ire1 // Nature. - 2009. - 457, N 7230. - P. 687-693.

6. Romero-Ramirez L., Cao H., Nelson D., Hammond E., Lee A. H., Yoshida H., Mori K., Glimcher L. H., Denko N. C., Giaccia A. J., Le Q. T., Koong A. C. XBP1 is essential for survival under hypoxic conditions and is required for tumor growth // Cancer Res. 2004. - 64, N 17. - P. 5943-5947.

7. Johnson A. B., Denko N., Barton M. C. Hypoxia induces a novel signature of chromatin modifications and global repression of transcription // Mutat. Res. - 2008. - 640. P. 174-179.

8. Denko N. C. Hypoxia, HIF1 and glucose metabolism in the solid tumour // Nat. Rev. Cancer. - 2008. - 8, N 9. - P. 705-713.

9. Aragón T., van Anken E., Pincus D., Serafimova I. M., Korennykh A. V., Rubio C. A., Walter $P$. Messenger RNA targeting to endoplasmic reticulum stress signalling sites // Nature. - 2009. - 457, N 7230. - P. 736-740.

10. Acosta-Alvear D., Zhou Y., Blais A., Tsikitis M., Lents N. H., Arias C., Lennon C. J., Kluger Y., Dynlacht B. D. XBP1 controls diverse cell typeand condition-specific transcriptional regulatory networks // Mol. Cell. - 2007. - 27, N 1. - P. 53-66.
11. Hollien J., Lin J. H., Li H., Stevens N., Walter P., Weissman J. S. Regulated Ire1-dependent decay of messenger RNAs in mammalian cells // J. Cell. Biol. - 2009. - 186, N 3. - P. 323- 331.

12. Lee J., Sun C., Zhou Y., Lee J., Gokalp D., Herrema H., Park S. W., Davis R. J., Ozcan U. p38 MAPK-mediated regulation of Xbp1s is crucial for glucose homeostasis // Nat. Med. 2011. - 17, N 10. - P. 1251-1260.

13. Park S. W., Zhou Y., Lee J., Lu A., Sun C., Chung J., Ueki K., Ozcan U. The regulatory subunits of PI3K, p85alpha and p85beta, interact with XBP-1 and increase its nuclear translocation // Nat. Med. - 2010. - 16, N 4. - P. 429-437.

14. Zhou Y., Lee J., Reno C. M., Sun C., Park S. W., Chung J., Lee J., Fisher S. J., White M. F., Biddinger S. B., Ozcan U. Regulation of glucose homeostasis through a XBP-1-FoxO1 interaction // Nat. Med. - 2011. - 17, N 3. - P. 356-365.

15. Drogat B., Auguste P., Nguyen D. T., Bouchecareilh M., Pineau R., Nalbantoglu J., Kaufman R. J., Chevet E., Bikfalvi A., Moenner M. IRE1 signaling is essential for ischemia-induced vascular endothelial growth factor-A expression and contributes to angiogenesis and tumor growth in vivo // Cancer Res. - 2007. - 67, N 14. - P. 6700-6707.

16. Auf G., Jabouille A., Guerit S., Pineau R., Delugin M., Bouchecareilh M., Favereaux A., Maitre M., Gaiser T., von Deimling A., Czabanka M., Vajkoczy P., Chevet E., Bikfalvi A., Moenner $M$. A shift from an angiogenic to invasive phenotype induced in malignant glioma by inhibition of the unfolded protein response sensor IRE1 // Proc. Natl. Acad. Sci. USA. 2010. - 107, N 35. - P. 1555-15558.

17. Hakelius M., Koskela A., Ivarsson M., Grenman R., Rubin K., Gerdin B., Nowinski D. Keratinocytes and head and neck squamous cell carcinoma cells regulate urokinasetype plasminogen activator and plasminogen activator inhibitor-1 in fibroblasts // Anticancer Res. - 2013. - 33, N 8. - P. 3113-3118.

18. Grismayer B., Sato S., Kopitz C., Ries C., Soelch S., Schmitt M., Baretton G., Krüger A., Luther T., Kotzsch M., Magdolen V. Overexpression of the urokinase receptor splice variant uPAR-del $4 / 5$ in breast cancer cells affects cell adhesion and invasion in a dose-dependent manner and modulates transcription of tumor- 
associated genes // Biol. Chem. - 2012. - 393, N 12. - P. 1449-1455.

19. Larusch G. A., Merkulova A., Mahdi F., Shariat-Madar Z., Sitrin R. G., Cines D. B., Schmaier A. $H$. Domain 2 of uPAR regulates single-chain urokinase-mediated angiogenesis through $\beta 1$-integrin and VEGFR2 // Am. J. Physiol. Heart Circ. Physiol. - 2013. - 305, N 3. - P. H305-H320.

20. Reymond N., Im J. H., Garg R., Vega F. M., Borda d'Agua B., Riou P., Cox S., Valderrama F., Muschel R. J., Ridley A. J. Cdc42 promotes transendothelial migration of cancer cells through $\beta 1$ integrin // J. Cell Biol. - 2012. - 199, N 4. - P. 653-668.

21. Chernyavsky A. I., Arredondo J., Galitovskiy V., Qian J., Grando S. A. Upregulation of nuclear factor-kappaB expression by SLURP-1 is mediated by alpha7-nicotinic acetylcholine receptor and involves both ionic events and activation of protein kinases // Am. J. Physiol., Cell Physiol. - 2010. - 299, N 5. - P. C903-C911.

22. Yu X., Zhen Y., Yang H., Wang H., Zhou Y., Wang E., Marincola F.M., Mai C., Chen Y., Wei H., Song Y., Lyu X., Ye Y., Cai L., Wu Q., Zhao M., Hua S., Fu Q., Zhang Y., Yao K., Liu Z., Li X., Fang W. Loss of connective tissue growth factor as an unfavorable prognosis factor activates miR-18b by PI3K/AKT/CJun and C-Myc and promotes cell growth in nasopharyngeal carcinoma // Cell Death Dis. 2013. - 4. - P. E634.

23. Lee S., Qiao J., Paul P., Chung D. H. Integrin $\beta 1$ is critical for gastrin-releasing peptide receptormediated neuroblastoma cell migration and invasion // Surgery. - 2013. - 154, N 2. - P. 369375.

24. MinchenkoD. O., KubajchukK. I., RatushnaO.O., Komisarenko S. V., Minchenko O. H. The effect of hypoxia and ischemic condition on the expression of VEGF genes in glioma U87 cells is dependent from ERN1 knockdown // Adv. Biol. Chem. - 2012. - 2, N 2. - P. 198-206.

25. Minchenko D. O., Karbovskyi L. L., Danilovskyi S. V., Moenner M., Minchenko O. H. Effect of hypoxia and glutamine or glucose deprivation on the expression of retinoblastoma and retinoblastoma-related genes in ERN1 knockdown glioma U87 cell line // Am. J. Mol. Biol. - 2012. - 2, N 1. - P. 21-31.

26. Dews M., Homayouni A., Yu D., Murphy D., Sevignani C., Wentzel E., Furth E. E., Lee W. M., Enders G. H., Mendell J. T., Thomas-Tikhonenko A. Augmentation of tumor angiogenesis by a Myc-activated microRNA cluster // Nat. Genet. - 2006. - 38, N 9. P. 1060-1065.

27. Inoki I., Shiomi T., Hashimoto G., Enomoto H., Nakamura H., Makino K., Ikeda E., Takata S., Kobayashi K., Okada Y. Connective tissue growth factor binds vascular endothelial growth factor (VEGF) and inhibits VEGF-induced angiogenesis // FASEB J. - 2002. - 16, N 2. P. 219-221.

28. Kenagy R. D., Min S. K., Mulvihill E., Clowes A. W. A link between smooth muscle cell death and extracellular matrix degradation during vascular atrophy // J. Vasc. Surg. - 2011. 54, N 1. - P. 182-191.

29. Simard B., Bouamrani A., Jourdes P., Pernod G., Dimitriadou $V$., Berger $F$. Induction of the fibrinolytic system by cartilage extract mediates its antiangiogenic effect in mouse glioma // Microvasc. Res. - 2011. - 82, N 1. - P. 6-17.

30. Kubaichuk K. I., Minchenko D. O., Danilovskyi S. V., Kuznetsova A. Y., Jasim A. R., Minchenko $O$. $H$. Hypoxic regulation of the expression of anti-angiogenic genes in U87 glioma cells with ERN1 signaling enzyme loss of function // Studia Biologica. - 2012. - 6, N 3. - P. 15-28. 